\title{
Neurology
}

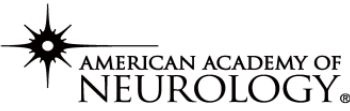

The most widely read and highly cited peer-reviewed neurology journal The Official Journal of the American Academy of Neurology

Neurology Publish Ahead of Print

DOI: 10.1212/WNL.0000000000013150

\section{Hemiparkinsonism Secondary to Giant Aneurysm}

Author(s):

Ana Gonçalves, MD ${ }^{1}$; João Oliveira, MD $^{2}$; Rita Simões, MD ${ }^{1}$; Nuno Canas, MD ${ }^{1}$; José Vale, MD ${ }^{1}$

Corresponding Author:

Ana Gonçalves

anaisabelgoncalvesf@gmail.com

Neurology® Published Ahead of Print articles have been peer reviewed and accepted for publication. This manuscript will be published in its final form after copyediting, page composition, and review of proofs. Errors that could affect the content may be corrected during these processes. 
Affiliation Information for All Authors: 1.Department of Neurology, Hospital Beatriz Ângelo, Loures, Portugal. 2. Department of Neuroradiology, Hospital Beatriz Ângelo, Loures, Portugal.

\section{Contributions:}

Ana Gonçalves: Drafting/revision of the manuscript for content, including medical writing for content; Major role in the acquisition of data; Study concept or design; Analysis or interpretation of data

João Oliveira: Major role in the acquisition of data; Study concept or design; Analysis or interpretation of data

Rita Simões: Drafting/revision of the manuscript for content, including medical writing for content; Study concept or design; Analysis or interpretation of data

Nuno Canas: Major role in the acquisition of data; Study concept or design; Analysis or interpretation of data

José Vale: Drafting/revision of the manuscript for content, including medical writing for content; Analysis or interpretation of data

Number of characters in title: 44

Abstract Word count: 100

Word count of main text: 100

References: 2

Figures: 2

Tables: 0

Neuroimage Legend Count: 49

\section{Supplemental: CONSET FOR PUBLICATION}

Search Terms: [ 13 ] Other cerebrovascular disease/ Stroke, [ 119 ] CT, [ 120 ] MRI, [ 123 ]

SPECT, [ 165 ] Parkinson's disease/Parkinsonism

Study Funding: The authors report no targeted funding

Disclosures: The authors report no disclosures relevant to the manuscript. 
An 81-year-old woman presented with progressive right levodopanonresponsive hemiparkinsonism for six months. Brain CTscan and MRI (Figure 1) showed a giant supraclinoid unruptured aneurysm of the left internal carotid artery, leading to severe left basal ganglia displacement and left cerebral peduncle compression.

She underwent loflupane SPECT (Figure 2) that showed decreased tracer binding exclusively in the left putamina and left caudate nuclei. The preserved pre-synaptic dopaminergic function of right basal nuclei ruled out an unmasked latent Parkinson's disease.

In this case, a giant aneurism induced pre-synaptic dopaminergic dysfunction. Absent levodopa benefit may support that left post synaptic pathway was affected as well. 
Figure $1-\mathrm{CT}$ and MRI demonstrating a giant unruptured aneurysm of the left supraclinoid internal carotid artery

Axial CTA (A, B and C); Coronal MIP thin (D); CTA three-dimensional posteroanterior reconstruction (E); T2-weighted axial MRI (F, G, H and I) and three-dimensional volume rendering $(J)$. The images demonstrate a partially thrombosed giant aneurism that exerts lateral displacement of the left basal ganglia and left cerebral peduncle.

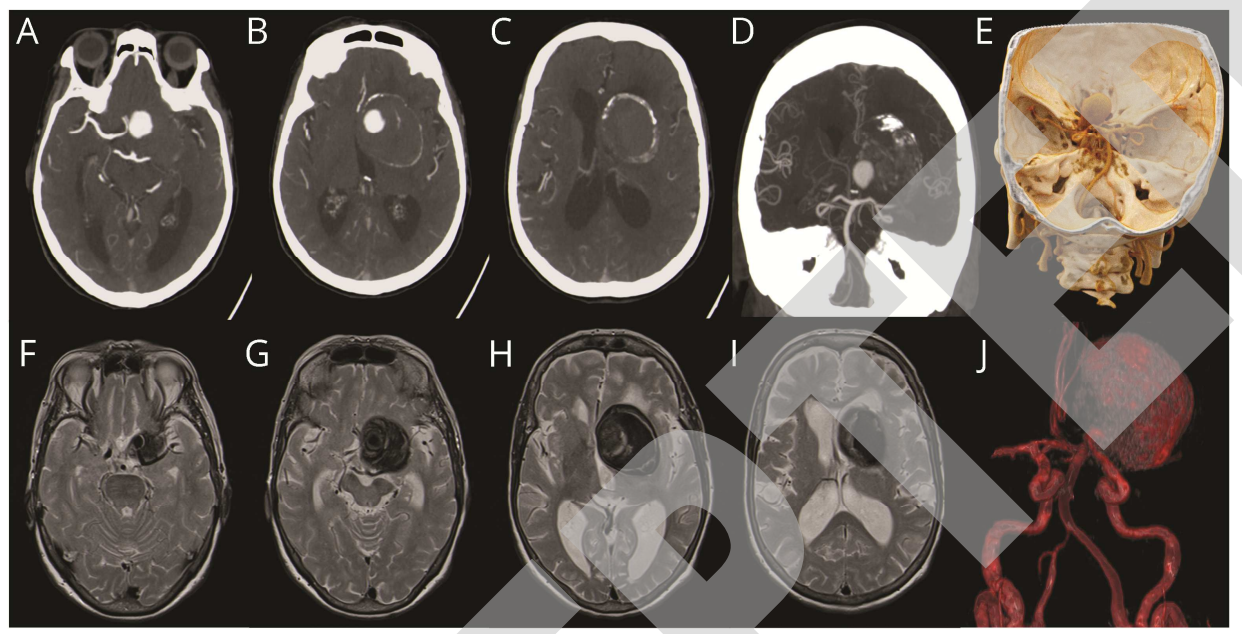

Figure 2 - loflupane (123I) SPECT

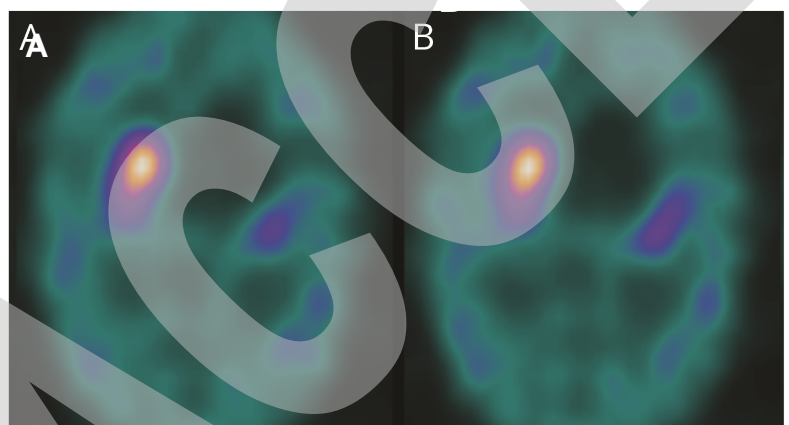

Axial loflupane (123I) SPECT images (A and B) demonstrate asymmetric activity with reduced loflupane uptake in left putamina and left caudate nuclei. Activity is preserved in the right hemisphere resulting in a comma shape. 
Appendix 1. Authors

\begin{tabular}{|c|c|c|c|}
\hline Name & Location & & Contribution \\
\hline $\begin{array}{l}\text { Ana } \\
\text { Gonçalves }\end{array}$ & $\begin{array}{l}\text { Hospital } \\
\text { Loures }\end{array}$ & Beatriz Ângelo, & $\begin{array}{l}\text { Study concept and design, } \\
\text { acquisition of data, drafting } \\
\text { the manuscript }\end{array}$ \\
\hline João Oliveira & $\begin{array}{l}\text { Hospital } \\
\text { Loures }\end{array}$ & Beatriz Ângelo, & $\begin{array}{l}\text { Study concept and design, } \\
\text { acquisition of data, drafting } \\
\text { the manuscript }\end{array}$ \\
\hline Rita Simões & $\begin{array}{l}\text { Hospital } \\
\text { Loures }\end{array}$ & Beatriz Âng & $\begin{array}{l}\text { Acquisition of data, analysis } \\
\text { and interpretation of data, } \\
\text { study supervision }\end{array}$ \\
\hline Nuno Canas & $\begin{array}{l}\text { Hospital } \\
\text { Loures }\end{array}$ & Beatriz Ângelo, & $\begin{array}{l}\text { Study concept and design, } \\
\text { critical revision of manuscript } \\
\text { for intellectual content. }\end{array}$ \\
\hline José Vale & $\begin{array}{l}\text { Hospital } \\
\text { Loures }\end{array}$ & triz & $\begin{array}{l}\text { Study concept and design, } \\
\text { critical revision of manuscript } \\
\text { for intellectual content. }\end{array}$ \\
\hline
\end{tabular}




\section{References}

1. Bostantjopoulou S, Katsarou Z, Petridis A, Aneurysm presenting as parkinsonism, Neurology 67 (11) (2006) (p. 2028-2028).

2. Sibon I, Rajabally Y, Tison F. Parkinsonism as a Result of a Giant Aneurysm. Movement Disorders 14 (1) (1999) 159-161. 


\title{
Neurology
}

\author{
Hemiparkinsonism Secondary to Giant Aneurysm \\ Ana Gonçalves, João Oliveira, Rita Simões, et al. \\ Neurology published online December 6, 2021 \\ DOI 10.1212/WNL.0000000000013150
}

This information is current as of December 6, 2021

\section{Updated Information \& Services}

Subspecialty Collections

Permissions \& Licensing

Reprints including high resolution figures, can be found at:

http://n.neurology.org/content/early/2021/12/06/WNL.0000000000013150. citation.full

This article, along with others on similar topics, appears in the following collection(s):

CT

http://n.neurology.org/cgi/collection/ct

MRI

http://n.neurology.org/cgi/collection/mri

Other cerebrovascular disease/ Stroke

http://n.neurology.org/cgi/collection/other_cerebrovascular_disease_stroke

Parkinson's disease/Parkinsonism

http://n.neurology.org/cgi/collection/parkinsons_disease_parkinsonism SPECT

http://n.neurology.org/cgi/collection/spect

Information about reproducing this article in parts (figures,tables) or in its entirety can be found online at:

http://www.neurology.org/about/about_the_journal\#permissions

Information about ordering reprints can be found online:

http://n.neurology.org/subscribers/advertise

Neurology $\AA^{\circledR}$ is the official journal of the American Academy of Neurology. Published continuously since 1951, it is now a weekly with 48 issues per year. Copyright (C) 2021 American Academy of Neurology. All rights reserved. Print ISSN: 0028-3878. Online ISSN: 1526-632X.

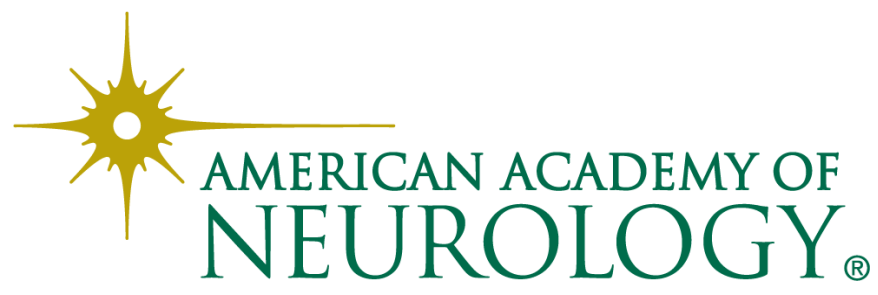

